\title{
Studi Analisa Gangguan Hubung Singkat Dengan Menggunakan Metode MVAhs (Hubung Singkat)
}

\author{
Edy Saputra' ${ }^{1}$, Susilawati ${ }^{1}$, Muhammad Adam², Abdul Munir Dalimunthe ${ }^{1}$ \\ ${ }^{1}$ Program Studi Teknik Elektro, Fakultas Teknik \\ Universitas Al Azhar Medan \\ Jl. Pintu Air IV No. 214, Kwala Bekala, Medan, Sumatera Utara Telp. (+62)(61)8366679 Kode pos 20142 \\ ${ }^{2}$ Program Studi Teknik Elektro, Fakultas Teknik \\ Universitas Muhammadiyah Sumatera Utara (UMSU) \\ Jl. Kapten Muchtar Basri,BA No. 03 Medan Telp. (061) 6622400 ex. 12 Kode pos 20238 \\ e-mail: edy_siraj@yahoo.co.id
}

\begin{abstract}
Abstrak - Metode MVA hubung-singkat (MVAhs) ini, dapat menjadi alternatif dari metode per-unit standart untuk studi hubung singkat. Dimana pada metode ini meniadakan kebutuhan akan besaran dasar, dan pada akhirnya mempresentasikan elemen sistem daya dalam bentuk MVA. Metode ini cukup sederhana dan tidak rentan dengan kesalahan yang tidak dikehendaki. Pada rangkaiannya terdiri dari 3 komponen yaitu, komponen urutan positif, komponen urutan negatif dan komponen urutan nol. Untuk memperoleh titik gangguan MVA hubung-singkat total dari proses penggabungan nilai-nilai setiap komponen. Didasari antara satu komponen dengan komponen yang lainnya, masing-masing yaitu : seri, paralel dan delta wye. Selanjutnya mencari MVAhs dengan cara penggabungan komponen-komponen yang ada pada urutan positif, negatif dan nol dengan menghubungkannya pada hubungan seri, paralel dan delta-wye. Demikian seterusnya, hingga diperoleh satu MVAhs urutan dengan menggabungkan MVAhs urutan dengan salah satu hubungan, akan diperoleh MVAhs total sistem, untuk suatu titik gangguan tertentu yang ditinjau. Maka nilai arus hubung-singkat (Ihs) $=0,338 \mathrm{KA}$.
\end{abstract}

Kata kunci : Metode MVA hubung-singkat (MVAhs)

\begin{abstract}
The short-circuit MVA (MVAhs) method can be an alternative to the standard per-unit method for short circuit studies. Where in this method eliminates the need for basic quantities, and in the end presents the power system elements in the form of MVA. This method is quite simple and not prone to unwanted errors. The circuit consists of 3 components, namely, a positive sequence component, a negative sequence component and a zero sequence component. To obtain the total short-circuit MVA fault points from the process of combining the values of each component. Based on one component with other components, respectively, namely: series, parallel and delta wye. Furthermore, looking for MVAhs by combining existing components in positive, negative and zero sequences by connecting them in series, parallel and delta-wye relationships. And so on, until one sequence MVAhs is obtained by combining the sequence MVAhs with one of the relationships, we obtain the total system MVAhs, for a particular fault point under review. Then the short-circuit current (Ihs) $=0.338 \mathrm{KA}$.
\end{abstract}

Keywords : $\quad$ Short-circuit MVA (MVAhs) method

\section{PENDAHULUAN}

Pada dasarnya, metode MVA-hubungan singkat ini, adalah suatu modifikasi dari metode ohmic dimana, impedansi rangkaian merupakan hasil penjumlahan impedansi-impedansi dari berbagai komponen di dalam rangkaian. Berdasarkan definisinya, admitansi adalah kebalikan dari impedansi, maka dengan sendirinya kebalikan dari admitansi sistem adalah sama dengan hasil penjumlahan kebalikan kebalikan admitansi komponen. Disamping itu harga admitansi suatu rangkaian atau komponen sama dengan harga arus atau harga KVA maksimum pada tegangan per unit yang akan mengalir melalui rangkaian atau komponen ke suatu titik gangguan bila mana mendapat suplai dari suatu sumber yang kapasitasnya tak terhingga.

Sehubungan dengan metode perhitungan gangguan sistem di atas, penulis tertarik untuk menganalisa setiap gangguan yang mungkin terjadi dengan menggunakan analisa gangguan hubung singkat dengan menggunakan metode MVAhs (Hubung Singkat).

Untuk mengetahui arus gangguan dalam suatu sistem dapat juga digunakan metode MVAhs, karena suatu sistem tenaga listrik tidak pernah luput dari gangguan, ,baik itu gangguan dalam sistem (internal) maupun gangguan dari luar sistem (external) bila mana metode ini digunakan dalam perhitungan arus gangguan maka dapat menghitung arus gangguan 
dengan menggunakan metode MVAhs (hubungan singkat).

Tujuan penulisan adalah menganalisa metode perhitungan MVAhs pada gangguan hubungan singkat dengan studi gangguan hubungan singkat menggunakan metode MVAhs (hubungan singkat).

Mengingat ruang lingkup permasalahan sangat luas, maka penulis di sini membuat suatu batasan masalah yang akan dibahas. Adapun masalah yang akan dibahas adalah Gangguan hubungan singkat satu fasa ke tanah.

\section{TINJAUAN PUSTAKA}

\section{A. Defenisi MVAhs}

Suatu metode yang meniadakan kebutuhan akan besaran dasar dengan merepresentasikan elemen sistem daya dalam bentuk MVA dan menunjukan suatu proses yang lebih sederhana sehingga tidak rentan dengan kesalahan yang tidak dikehendaki. Pada dasarnya, metode MVA-hubungan-singkat dalam suatu modifikasi dari metode ohmic dimana, impedans rangkaian merupakan hasil penjumlahan impedans-impedans dari berbagai komponen di dalam rangkaian. Berdasarkan definisinya, admitansi adalah kebalikan dari impedansi, maka dengan sendirinya kebalikan dari admitansi sistem adalah sama dengan hasil penjumlahan kebalikan kebalikan admitansi komponen. Disamping itu harga admitansi suatu rangkaian atau komponen sama dengan harga arus atau harga KVA maksimum pada tegangan per unit yang akan mengalir melalui rangkaian atau komponen kesuatu titik gangguan bila mana mendapat suplai dari suatu sumber yang kapasitasnya tak terhingga.

Pada gambar, untuk gangguan yang terjadi dititik $\mathrm{F}$, arus hubungan singkat pada titik tersebut dapat diperoleh.

\section{Rel tak terhingga}

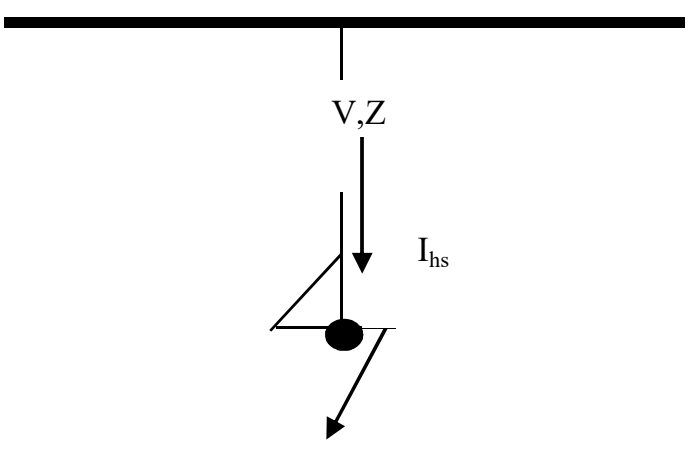

Gambar 1 Diagram Satu Garis
Dari diagram 1 satu garis, untuk $\mathrm{V}$ dan $\mathrm{Z}$ yang diketahui, maka :

$$
\begin{aligned}
& I_{h s}=\frac{V}{Z} \\
& \sqrt{3}(\sqrt{3} .) V I_{h s}=\sqrt{3}(\sqrt{3} .) V \cdot \frac{V}{Z} \\
& \sqrt{3} V_{L L} I_{h s}=\frac{V_{L L}{ }^{2}}{Z}
\end{aligned}
$$

Atau

$$
\begin{aligned}
M V A_{h s} & =\frac{1000 K(V)^{2}}{Z} \\
M V A_{h s} & =\frac{(K V)^{2}}{Z}
\end{aligned}
$$

atau

$$
M V A_{h s}=\frac{(M V A)}{Z_{p u}} \ldots \ldots \ldots \ldots \ldots \ldots \ldots
$$

Dimana :

$\mathrm{VLL}=$, tegangan fase ke fase (Volt)

Ihs = arus hubungan singkat (Ampere)

$\mathrm{V} \quad=$ tegangan fase ke netral (Volt)

$\mathrm{Z} \quad=$ impedansi fase ke netral (Ohm)

$\mathrm{Zpu}=$ impedansi fase ke netral (pu)

MVAhs = daya hubung singkat (MVA)

MVA = rating daya (MVA)

Pada prinsipnya, penggunaan metode ini, dilakukan dengan melihat rangkaian sebagai komponen-komponen, kemudian menghitung MVAhs tiap komponen, menghitung MVAhs total (sistem) lalu menghubungkannya ke rel tak terhingga.

\section{B. Komponen Simetris}

Suatu sistem tak seimbang yang terdiri dari $n$ fasor-fasor yang berhubungan dapat diuraikan menjadi $\mathrm{n}$ buah sistem dengan fasor-fasor seimbang yang dinamakan komponen-komponen simetris dari fasor-fasor aslinya. $\mathrm{N}$ buah fasor pada setiap himpunan komponen-komponen adalah sama panjang, dan sudut-sudut diantara fasor-fasor yang bersebelahan dalam himpunan itu adalah sama besarnya. Jadi tiga fasor tak seimbang dari suatu sistem tiga fasa dapat diuraikan menjadi tiga sistem fasor yang seimbang. Himpunan-himpunan seimbang dari komponen-komponen itu adalah :

$\square$ Komponen-komponen urutan positif, yang terdiri dari tiga fasor yang sama besar, terpisah satu dengan yang lain dalam fasa sebesar 1200 dan mempunyai urutan fasa yang sama seperti fasor aslinya.

$\square$ Komponen-komponen urutan negatif, yang terdiri dari tiga fasor yang sama besarnya terpisah satu dengan yang lain dalam fasa sebesar 1200 dan mempunyai urutan fasa yang berlawanan dengan fasor-fasor aslinya.

$\square$ Komponen-komponen urutan nol, yang terdiri dari tiga fasor yang sama besarnya dan dengan pergeseran fasa nol antara fasa yang satu dengan yang lain. 
Biasanya, ketika memecahkan permasalahan dengan menggunakan komponen simetris bahwa ketiga fasa dari sistem dinyatakan sebagai $\mathrm{a}, \mathrm{b}$ dan $\mathrm{c}$ dengan cara yang demikian sehingga urutan fasa tegangan dan arus dalam sistem adalah abc, sedangkan urutan fasa dari komponen negatif adalah acb. Jika fasor aslinya adalah tegangan, maka tegangan tersebut dapat dinyatakan dengan $\mathrm{Va}, \mathrm{Vb}$, dan Vc. Ketiga himpunan komponen simetris dinyatakan dengan subskrip tambahan 1 untuk komponen urutan nol. Komponen urutan positif dari $\mathrm{Va}, \mathrm{Vb}$ dan Vc adalah Va1, Vb1, dan Vc1. Demikian pula, komponen urutan negatif adalah $\mathrm{Va} 2, \mathrm{Vb} 2$, dan $\mathrm{Vc} 2$, sedangkan komponen urutan nol adalah $\mathrm{Va0}$, dan Vc0. Gambar. menunjukkan tiga himpunan komponen simetris semacam itu. Fasor arus akan dinyatakan dengan I dengan subskrip seperti untuk tegangan . Karena setiap fasor tak seimbang, yang asli adalah juga komponen, fasor asli yang dinyatakan dalam suku-suku komponennya adalah :

$$
\begin{aligned}
& \mathrm{Va}=\mathrm{Va} 1+\mathrm{Va} 2+\mathrm{Va} 0 \\
& \mathrm{Vb}=\mathrm{Vb} 1+\mathrm{Vb} 2+\mathrm{Vb} 0 \\
& \mathrm{Vc}=\mathrm{Vc} 1+\mathrm{Vc} 2+\mathrm{Vc} 0
\end{aligned}
$$

Sintesis himpunan tiga fasor tak seimbang dari ketiga himpunan komponen simetris dalam gambar berikut.
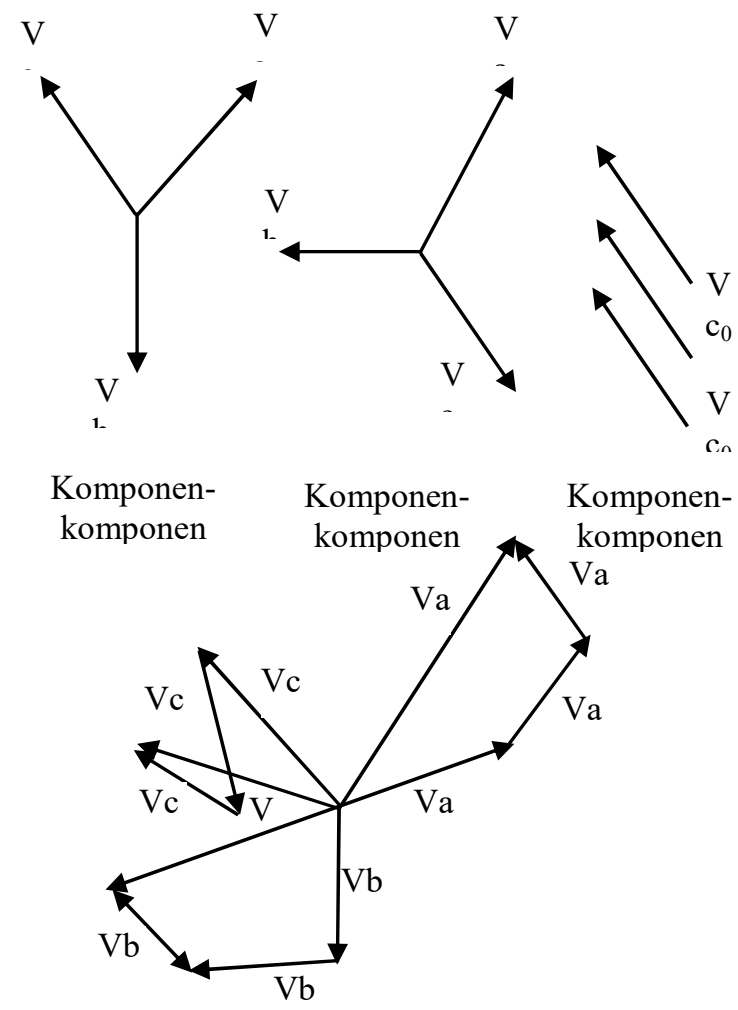

Gambar 2 Tiga Himpunan Fasor Tak Simbang Yang Merupakan Simetris Dari Tiga Fasor Tak Simbang
Penjumlahan Secara Grafis Komponen-Kompen Pada Gambar diatas Untuk Mendapatkan Tiga Fasor Tak Simbang

\section{Impedansi Urutan Dan Jaringan Urutan}

Dalam setiap bagian rangkaian, jatuh tegangan yang disebabkan oleh arus dengan urutan tertentu tergantung pada impedansi bagian rangkaian itu terhadap arus dengan urutan tersebut. Impedansi setiap bagian suatu jaringan yang seimbang terhadap arus salah satu urutan dapat berbeda dengan impedansi terhadap arus dari urutan lain.

Impedansi suatu rangkaian yang hanya mengalir arus urutan positif disebut impedansi terhadap arus urutan positif. Demikian pula, bila hanya ada arus urutan negatif, impedansinya dinamakan impedansi terhadap arus urutan negatif. Jika hanya ada urutan nol, impedansinya dinamakan impedansi terhadap arus urutan nol. Sebutan impedansi rangkaian terhadap arus dari urutan yang berbeda ini biasanya disingkat menjadi istilah yang sebenarnya kurang jelas artinya, yaitu impedansi urutan positip, impedansi urutan negatif dan impedansi urutan nol. Analisa suatu gangguan tak simetris pada suatu sistem yang simetris terdiri dari penentuan komponen-komponen simetris dari arus-arus tak seimbang yang mengalir. Karena arus-arus komponen dari salah satu urutan fasa menimbulkan teganganjatuh dengan urutan yang sama dan tidak tergantung pada arus-arus dari urutan-urutan yang lain, dalam suatu sistem yang seimbang arus-arus dari salah satu urutan dapat dianggap mengalir dalam suatu jala-jala bebas yang terdiri hanya dari impedansi-impedansi terhadap arus dari urutan. Rangkaian ekivalen fasatunggal yang hanya terdiri dari impeansi-impedansi terhadap arus dari salah satu urutan dinamakan jalajala urutan untuk urutan tersebut. Jala-jala urutan meliputi setiap emf yang dibangkitkan pada urutan yang sama. Jala-jala urutan yang mengalirkan arusarus Ia1,Ia2 dan $\mathrm{Ia} 0$ diinterkoneksikan untuk melukiskan berbagai-bagai keadaan gangguan yang tak seimbang. Karena itu, untuk menghitung pengaruh suatu gangguan dengan metode komponenkomponen simetris, adalah penting sekali untuk menentukan impedansi-impedansi urutannya dan menggabungkannya untuk membentuk jala-jala urutannya.

Analisa suatu gangguan tak simetris pada suatu sistem yang simetris terdiri dari penentuan penentuan komponen simetris dari arus-arus tak seimbang yang mengalir. Karena arus-arus komponen dari salah satu urutan fasa menimbulkan tegangan-jatuh dengan urutan yang sama saja dan tidak tergantung pada arus-arus dari urutan urutan yang lain, dalam suatu sistem yang siembang arus-arus dari salah satu urutan dapat dianggap dalam suatu jala-jala bebas yang terdiri dari impedansi-impedansi terhadap dari urutan itu saja. Jala-jala urutan meliputi setiap emf yang 
dibangkitkan pada urutan yang sama. Jala-jala urutan yang mengalir

\section{Jaringan Urutan Generator Tak Berbeban}

Suatu generator tak berbeban, yang ditanahkan melalui reaktor, dapat dilihat dalam gambar. Bila gangguan (yang tidak diperlihatkan dalam gambar) terjadi pada terminal generator itu, maka Ia, Ib, dan Ic akan mengalir dalam salurannya. Jika gangguan tersebut melibatkan tanah, arus yang mengalir ke netral generator dinyatakan sebagai In. Salah satu atau dua dari arus saluran dapat sama dengan nol, tetapi arus itu dapat diuraikan ke dalam komponen simetrisnya tanpa memandang. bagaimana ketida kseimbangan

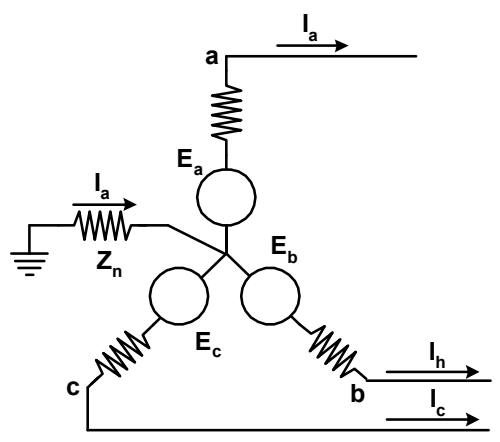

Gambar 3 Suatu generator tak berbeban

Diagram Rangkaian Suatu Generator Tanpa Beban Yang Ditanahkan Melalui Suatu Reaktansi. Emf Masing-Masing Fasa Ini Adalah Ea, Eb, dan Ec' Menggambar jaringan urutan itu adalah sangat mudah. Tegangan yang dibangkitkan hanyalah dari urutan positif saja, karena generator tadi dirancang untuk mencatu tegangan tiga fasa seimbang. Oleh karena itu, jaringan urutan positif terdiri dari suatu emf dalam hubungan seri dengan impedansi urutan positif generator itu. Jaringan urutan negatif dan urutan nol. Komponen urutan arus ditunjukkan pada gambar. Arus itu mengalir melalui impedansi urutannya sendiri, setiap ditunjukkan oleh subskrip yang bersesuai pada impedansi yang diperlihatkan dalam gambar itu. Jaringan urutan yang lihat pada gambar adalah rangkaian ekivalen fasa tunggal dari rangkaian tiga fasa yang seimbangnya. Emf yang dibangkitkan pada jaringan urutan positif adalah tegangan terminal ke netral pada keadaan tak berbeban, yang juga sama dengan tegangan internal peralihan dan sub-peralihan karena generatornya tidak dibebani. Reaktansi pada jaringan urutan positif adalah reaktansi sub-peralihan, peralihan, atau serempak, tergantung pada apakah keadaan yang sedang dibahas itu dalam keadaan sub-peralihan, peralihan, atau keadaan-tetap.

Rel pedoman untuk jaringan urutan positif dan negatif adalah netral generator tersebut. Bagi komponen urutan positif dan negatif itu sendiri netral generator berada pada potensial tanah jika diantara netral tanah terhadap sambungan yang mempunyai impedansi tertentu atau nol, karena sumbangan tersebut tidak akan mengalirkan arus urutan positif atau negatif.

Arus yang mengalir pada impedansi $\mathrm{Zn}$ diantara netral dan tanah adalah 3Ia0. Dengan berpedoman pada gambar kita lihat bahwa jatuhnya tegangan urutan nol dari titik a ke tanah adalah -3Ia0Zn Ia0Zg0. Dimana Zg0 adalah impedansi urutan nol per fasa pada generator itu. Jaringan urutan nol-nya, yang merupakan rangkaian fasa tunggal yang dianggap hanya mengalirkan arus urutan nol salah satu fasanya

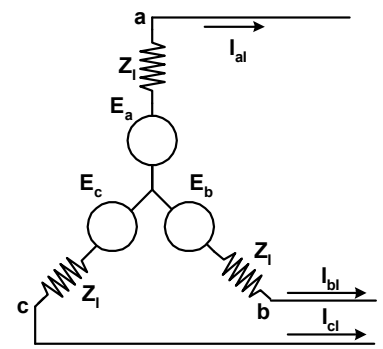

(a) Jalur-jalur arus urutan positif

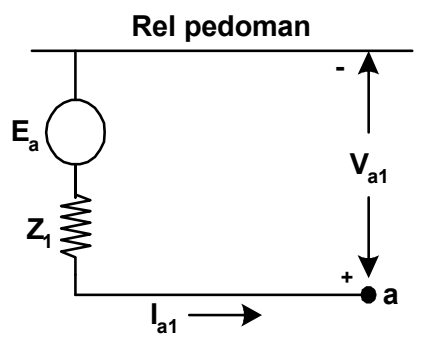

(b) Jala-jala arus urutan positif

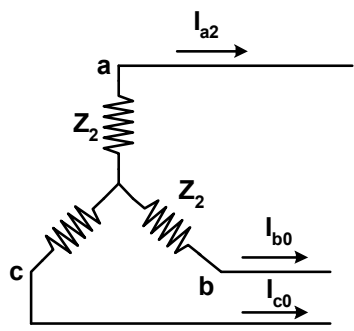

(c) Jalur-jalur arus urutan negatif

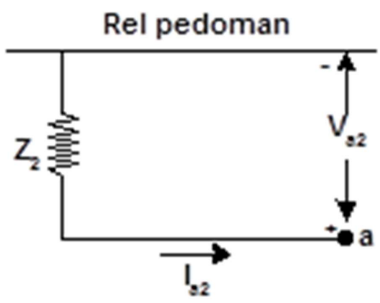

(d) Jala-jala arus urutan negatif 


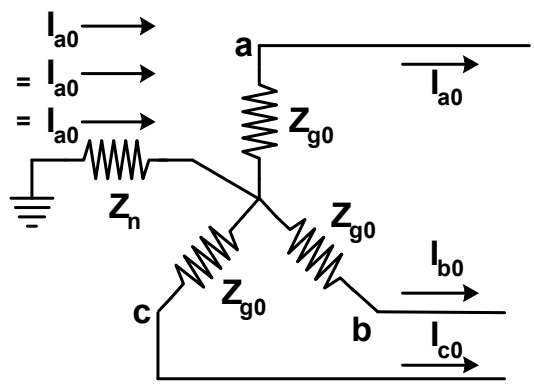

(e) Jalur-jalur arus urutan nol

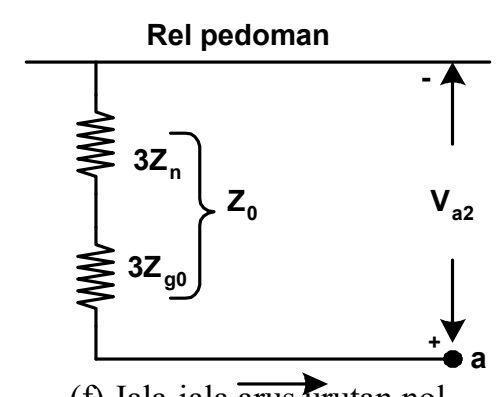

(f) Jala-jala $\underset{\operatorname{arys} \text { urutan nol }}{\mathrm{a}}$

Gambar 4 Jalur yang digambarkan untuk arus pada setiap urutandalam Generator dan jaringan urutan yang bersesuaian.

Impedansi urutan nol total dimana mengalir arus $\mathrm{Ia} 0 \neg$ adalah :

$$
\mathrm{Z0}=3 \mathrm{Zn}+\mathrm{Za} 0
$$

Biasanya, komponen arus dan tegangan untuk fasadiperoleh dari persamaan yang ditentukan oleh jaringan urutannya. Persamaan untuk komponen jatuh tegangan dari titik a fasa ke a rel pedoman adalah, sebagaimana dapat diturunkan.

$$
\begin{aligned}
& \mathrm{Va} 10=\mathrm{Ea}+\mathrm{Ia} 1 \mathrm{Z} 1 \\
& \mathrm{Va} 2=-\mathrm{Ia} 2 \mathrm{Z} 2 \\
& \mathrm{Va} 0=-\mathrm{Ia} 0 \mathrm{Z} 0
\end{aligned}
$$

Dimana Ea adalah tegangan tanpa beban urutan positif ke netral, Z1 dan Z2 impedansi urutan positif dan negatif generator, dan Z0 didefenisikan oleh persamaan. Persamaan diatas yang berlaku untuk setiap generator yang mengalir arus seimbang merupakan titik tolak untuk menurunkan persamaan tadi untuk komponenarus dari bermacam-macam jenis gangguan. Persamaan itu berlaku untuk generator yang dibebani dalam keadaan tetap. Bila kita menghitung keadaan peralihan atau sub-peralihan, maka persamaan itu berlaku untuk generator yang dibebani hanya jika $\mathrm{E} \square \mathrm{g}$ atau $\mathrm{E} \square \mathrm{g}$ digantikan dengan Ea.

\section{E. Jenis-jenis Gangguan}

Dalam sistem tenaga listrik, bagian yang paling sering terkena gangguan adalah kawat transmisinya (kira-kira 70\% s/d 80\% dari saluran tegangan). Hal ini disebabkan luasnya dan panjangnya kawat transmisi yang terbentang dan yang beroperasi pada kondisi udara yang berbeda-beda. Pada sistem transmisi, suatu ganggun dapat terjadi disebabkan kesalahan mekanis, thermis tegangan lebih atau karena material yang cacat atau rusak, misalnya gangguan hubungan singkat, gangguan ketanah atau konduktor yang putus. Busur panah yang menetap merupakan gangguan yang sangat ditakuti sebab busur tanah yang padam dan menyala merupakan sumber gelombang berjalan yang mempunyai muka yang curam yang dapat membahayakan isolasi dari alat-alat instalasi walaupun letaknya jauh dari titik gangguan. Gangguan yang sering terjadi ialah gangguan hubungan singkat. Besar dari arus hubungan singkat itu tergantung dari jenis dan sifat gangguan hubungan singkat itu. Kapasitas dari sumber daya, kongfigurasi dari sistem, metode hubungan netral dari trafo, jarak gangguan dari unit pembangkit, angka pengenal dari peralatan-peralatan utama dan alat-alat pembatas arus, lamanya hubungan singkat itu dan kecepatan beraksi dari alat-alat pengaman.

Gangguan-gangguan singkat itu tidak hanya dapat merusak peralatan atau elemen-elemen sirkuit, tetapi juga dapat menyebabkan jatuhnya tegangan dan frekuensi sistem, sehingga kerja paralel dari unit-unit pembangkit menjadi tergantung pula.

Akibat-akibat yang disebabkan gangguan antara lain :

1. Menginterupsi kontinuitas pelayan daya kepada para konsumen apabila gangguan itu sampai menyebabkan terputusnya suatu rangkaian (sirkuit) atau menyebabkan keluarnya suatu unit pembangkit.

2. Penurunan tegangan yang cukup besar menyebabkan rendahnya kualitas tenaga listrik dan merintangi kerja normal pada peralatan konsumen.

3. Pengurangan stabilitas sistem dan menyebabkan jatuhnya generator.

4. Merusak peralatan pada daerah terjadinya gangguan itu.

Faktor-faktor yang dapat menyebabkan terjadinya gangguan pada sistem transmisi tegangan tinggi ialah :

1. Surja petir atau surja hubung Dari pengalaman diperoleh bahwa petir sering menyebabkan gangguan pada sistem tegangan tinggi sampai 150-220 KV. Sedangkan pada sistem diatas 380 $\mathrm{KV}$, yang menjadi sebab utamanya ialah surja hubung.

2. Burung atau daun-daun; Jika burung dan daundaun terbang dekat pada isolator gantung dari saluran transmisi, maka clearance (jarak aman) menjadi berkurang sehingga ada kemungkinan terjadi loncatan api.

3. Polusi (debu) Debu-debu yang menempel pada isolator merupakan konduktor yang bisa menyebabkan terjadinya loncatan api.

4. Pohon-pohon yang tumbuh didekat saluran transmisi. 
5. Retak-retak pada isolator maka secara mekanis apabila ada petir yang menyambar akan terjadi tembus (breakdown) pada isolator.

Klasifikasi dari gangguan dari dua segi yaitu :

1. Dari macam-macam gangguan :

a. Gangguan dua fasa atau tiga fasa melalui tahapan hubungan tanah.

b. Gangguan fasa ke fasa

c. Gangguan dua fasa ke tanah

d. Gangguan satu fasa ke tanah atau gangguan tanah.

2. Dari lamanya waktu gangguan :

a. Gangguan permanen

b. Gangguan temporer

Gangguan temporer yaitu apabila gangguan terjadi dalam hanya waktu yang singka saja dimana kemudian sistem kembali pada keadaan normal. Misalnya gangguan yang disebabkan oleh petir atau burung, dimana terjadi loncatan api pada isolasi udara atau minyak. Gangguan permanen baru dapat dihilangkan atau diperbaiki setelah bagian yang terganggu itu isolir dengan bekerjanya pemutus daya.

Dari pengalaman telah ditunjukkan bahwa makin tinggi tegangan suatu sistem, frekuensi terjadinya gangguan makin kecil, dan gangguan hubungan singkat yang paling banyak terjadi adalah gangguan satu fasa ke tanah, dimana faktor penyebabnya yang paling sering adalah petir. Tetapi untuk sistem transmisi diatas $380 \mathrm{KV}$ penyebab utama gangguan biasanya adalah surja hubung

\section{METODE}

\section{A. Pengambilan Data Penelitian}

Untuk dapat menghitung hasil dari hubungan singkat dengan metode MVAhs, maka disini akan diberi data-data sebagai berikut :

Tabel 1 Data pengukuran Nilai phasa

\begin{tabular}{|c|c|c|c|c|c|}
\hline Komponen & $\begin{array}{c}\text { Kemampuan } \\
\text { (MVA) }\end{array}$ & $\begin{array}{c}\text { Tegangan } \\
\text { (KV) }\end{array}$ & $\mathbf{X}_{\mathbf{d}}$ & $\mathbf{X}_{\mathbf{d}}$ & $\mathbf{X}^{\prime \boldsymbol{\prime}_{\mathbf{d}}}$ \\
\hline $\mathrm{G}_{1}$ & 100 & & 21 & 14 & 6 \\
$\mathrm{G}_{2}$ & 100 & 12.7 & 21 & 14 & 6 \\
$\mathrm{~T}_{1}$ & 100 & 11.6 & 21 & 21 & 21 \\
$\mathrm{~T}_{2}$ & 100 & $12.7 / 150$ & 31 & 31 & 31 \\
$\mathrm{~T}_{3}$ & 100 & $11.6 / 150$ & 25 & 25 & 25 \\
$\mathrm{~T}_{4}$ & 100 & $12.7 / 150$ & 35 & 35 & 35 \\
$\mathrm{~L}_{2-3}$ & 100 & & 15 & 15 & 35 \\
$\mathrm{~L}_{5-6}$ & 100 & & 22 & 22 & 55 \\
\hline
\end{tabular}

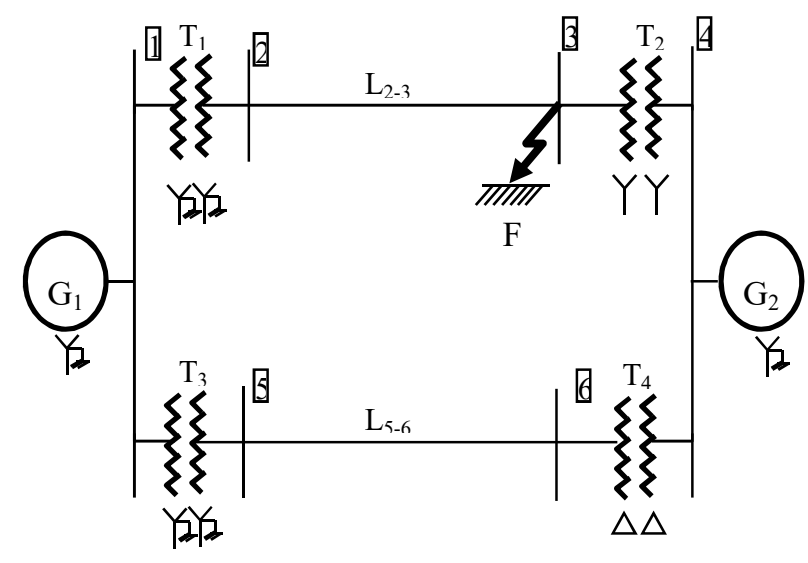

Gambar 5 Rangkaian One Line Diagram

\section{HASIL DAN PEMBAHASAN}

Hasil penelitian dibahas pada perhitungan berikut ini:

Perhitungan MVAhs Komponen-komponen

Sistem

- Generator

$\mathrm{G} 1=100 \mathrm{MVA} ; \mathrm{X} \square \mathrm{d} 21 \% \mathrm{MVAhs}=476 \mathrm{MVA}$ $\mathrm{G} 1=\mathrm{G} 2$

- Saluran :

$$
\begin{aligned}
\text { L2-3 } & =100 \text { MVA; } \mathrm{X} \square \mathrm{d}=15 \% \text { MVAhs }= \\
& =666 \text { MVA } \\
\text { L5-6 } & =100 \text { MVA; } \mathrm{X} \square \mathrm{d}=22 \% \text { MVAhs }= \\
& =454 \text { MVA }
\end{aligned}
$$

* $\quad \frac{476.666}{476+666}$

$=\frac{317016}{1142}$

$=277 \mathrm{MVA}$

$\frac{1}{400}+\frac{1}{454}+\frac{1}{285}=\frac{1}{51756000^{10}}$

$\frac{\left(51756000^{10} / 400\right)+\left(51756000^{10} / 454\right)+\left(51756000^{10} / 285\right)}{51756000^{10}}$

$\frac{129390+114000+181600}{51756000^{10}}$

$=\frac{424990}{51756000^{10}}$

$=\frac{51756000^{10}}{424990}$

$=121 \mathrm{MVA}$ 


\section{KESIMPULAN}

Kita dapat mengetahui nilai komponen-komponen sistem dengan menggunakan perhitungan MVAhs komponen-komponen sistem yang terdiri dari beberapa urutan yaitu :

a. Nilai komponen urutan positif $=367 \mathrm{MVA}$

b. Nilai komponen urutan negatif $=420 \mathrm{MVA}$

c . Nilai komponen urutan nol $=161 \mathrm{MVA}$

Dengan menghitung nilai komponen urutan positif, nilai komponen urutan negatif dan nilai komponen urutan nol dengan menggunakan perhitungan MVAhs total sistem kita dapat mengetahui nilai MVAhs total sistemnya $=88$ MVA, maka kita akan dapatkan nilai arus hubung-singkat (Ihs) $=0,338 \mathrm{KA}$.

\section{DAFTAR PUSTAKA}

[1] J. Clerk Maxwell, A Treatise on Electricity and Magnetism, $3^{\text {rd }}$ ed., vol. 2. Oxford: Clarendon, 1892, pp.68-73.
[2] Chen, T., H. "Application of The Complete Short-circuit MVA Method to Power Flow Studies", Electric Power System Research 38 (1996) 135-143.

[3] Stevenson, Jr., William, D. "Analisa Sistem Tenaga Listrik," Edisi ke empat penerbit Erlangga, 1984.

[4] Knable, Alvin H. "Electric Power Systems Engineering, Problems and Solutions", McGraw-Hill Book Company, 1967.

[5] Grainger, John, J., Stevenson, Jr., William, D. "Power System Analysis", Mcgraw-Hill, Inc., 1994.

[6] Chen, T.H "Complex short circuit MVA method for power system studies", IEE Proc. Gener. Tansm. Distrib., 141 (2) (1994) 81-84.

[7] Sunil L. Rao Switchgear And Protection”

[8] Turan Gonen "Modern Power System Analisis" 